\title{
STATE STATUTES THAT EXEMPT FAVORED INDUSTRIES FROM MEETING HIGHWAY WEIGHT RESTRICTIONS: \\ CONSTITUTIONALITY UNDER THE EQUAL PROTECTION CLAUSE
}

\section{INTRODUCTION}

Included among the statutes of each state are laws that regulate the size and weight of vehicles traveling upon public highways. Such regulations represent a vahid exercise of a state's pohce power to act in the interest of public health and safety. ${ }^{1}$ Although most of these statutory schemes apply uniformly, several differentiate and discriminate according to the class of carrier operated, the nature of the business involved, or the type of commodity carried. ${ }^{2}$ These statutes exempt specified car-

1. See Sproles v. Binford, 286 U.S. 374, 388 (1932); see also Gutridge v. Virginia, 532 F. Supp. 533, 539 n.4 (E.D. Va. 1982) ("Vehicle weight limits are an essential part of a highway safety program, because the amount of damage to the roads and danger to the traveling public rises as the weights of vehicles increase.") (citing Southern Pac. Co. v. Arizona, 325 U.S. 761, 783 (1945); South Carolina State Highway Dep't v. Barnwell Bros., 303 U.S. 177, 194-95 (1938)).

2. See, e.g., ALA. CODE $\$ 32-9-23$ (1983) (exempting vehicles liauling refrigerated inilk for luunan consumption from weight restriction); CAL. VEH. CODE $\S 35552$ (West Supp. 1984) (allowing higher weight limitation to vehicles loaded solely with logs); GA. CODE ANN. § 32-626(g)(1) (Supp. 1984) (allowing higher weight limitation to vehicles hauling the following products within the same county or adjoining counties: forest products from the place of cutting to the owner's place of business, plant, plantation, or residence; live poultry from a farm to a processing plant; feed from a mill to a farm; granite from a quarry to a processing plant); ILL. ANN. STAT. ch. 95\%, § 15-101(b) (Smith-Hurd Supp. 1984) (exeinpting from weight restrictions implements of husbandry liauling fresh, perishable frnits or vegetables from farm to point of first processing); ME. REv. Stat. ANN. tit. 29, \& 1655 (Supp. 1983) (allowing higher weight limitation to vehicles loaded entirely with firewood, sawed lumber, dimension lunber, pulpwood, wood chips, logs, soils, unconsolidated rock materials, bolts, farm produce, inanufacturer's concrete products, building materials which absorb moisture during dehivery within the state, and raw ore, vehicles loaded with a majority of refrigerated products, and vehicles of the following types: dump trucks, tractor dump trucks, and transit mix concrete trucks carrying highway construction materials); MD. TRANSP. CODE ANN. § 24-111.1 (1984) (allowing higher weight limitation to vehicles carrying liquid milk in bulk from the producer and excusing one violation per year by drivers carrying perishable products exclusively); S.C. CoDE ANN. § 56-5-4020 (Law. Co-op. Supp. 1983) (exempting from weight limitations vehicles carrying implements and products of liusbandry, including vehicles used to transport, store, or spread soil improvement products for agriculturai purposes); VA. CODE $\$ \S 46.1-343,343.1$ (Supp. 1984) (exempting froin weight restriction any vehicle carrying containerized cargo in a sealed, seagoing container boumd to or from a Virginia seaport, special vehicles used in hauling coal, three-axle vehicles used exclusively for mixing concrete in transit or at a project site or for transporting necessary components to produce concrete upon immediate 
riers from meetimg the limits to which others must conform and create what appear to be inequities. Trucking companies and businesses that are identical to exempted haulers in every way except for the statutory basis for distinction must comply with inore stringent regulations or face prosecution for failing to do so. Questions of equal protection that arise in the area of roadway regulation, however, receive only limited judicial scrutiny. ${ }^{3}$ Courts are expected to, and often do, defer to legislative judgment, conducting the relaxed examination for rationality typical of substantive equal protection cases. ${ }^{4}$ Despite judicial passivity in this area, soine recourse may be available to those subject to this form of economic discrimination.

This note will examine the split of authority among courts that have grappled with these statutes in recent years. ${ }^{5}$ It undertakes an examination of equal protection doctrine in the area of public safety and highway regulation in order to ascertain the scope of judicial review that properly may be apphed to highway weight restriction statutes. ${ }^{6}$ The objective is to clarify the circumstances under which an equal protection remedy may exist for parties upon whoin an econounic burden falls.

\section{Principles of Equal Protection Review: The Rational BASIS STANDARD}

The first step in equal protection review is to assess the nature of the statute in question. The typical highway weight restriction statute contains a series of maximum gross weight limits that are based upon vehicle type and axle specifications. ${ }^{7}$ These standards are generally determined by the number of axles and the distance between groups of axles; the greater the number, the distance, or both, the greater the permissible weight. This classification is based upon a recogmition of the important relationship between weight distribution and the statutory aims of highway mamtenance and safety. Contrast this classification,

arrival at a project site, and vehicles hauling farm produce on the state's Eastern Shore). That the carriers of such an assortment of products are accorded preferential statutory treatment suggests that more is at work than the protection of state roadways and the public health and safety. More likely, the aim is to provide an economic advantage to the industries selected.

3. See, e.g., Sproles v. Binford, 286 U.S. 374, 388-89 (1932).

4. See, e.g., Gutridge v. Virginia, 532 F. Supp. 533, 537 (E.D. Va. 1982). Particularly where the police power of a state is involved, courts refuse to inquire into the substantive wisdom of or motive for a legislative enactment and will act with deference whenever a rational basis may possibly be inferred. Id; see infra notes 39-52 and accompanying text.

5. See infra notes $18-52$ and accompanying text.

6. See infra notes 53-94 and accompanying text.

7. See, e.g., Or. Rev. STAT. $\S 483.506$ (1983); VA. CODE $\S 46.1-339$ (Supp. 1984). 
however, with one based upon the type of product that a vehicle carries. Statutes incorporating such classifications allow carriers of poultry, ${ }^{8}$ lumber, ${ }^{9}$ milk, ${ }^{10}$ coal, ${ }^{11}$ or other diverse products to exceed lawful weight limits without penalty solely because of the nature of the cargo. The relationship between this type of classification and the statutory aim is less clear.

It is evident that highway weight restriction statutes and exemptions result in economic discrimination. Courts presently review alleged instances of economic discrimination pursuant to a "rational basis" test ${ }^{12}$ that grants state legislatures wide discretion in enactimg

8. See, e.g., GA. CODE ANN. § 32-6-26(g)(1) (Supp. 1984).

9. See, e.g., CAL. Veh. Code $\$ 35552$ (West Supp. 1984); OR. Rev. StAT. $\$ 483.506$ (1983).

10. See, e.g., Ala. CODE § 32-9-23 (1983); MD. TRansp. Code ANn. § 24-111.1 (1984).

11. See, e.g., VA. CODE $\& 46.1-343$ (1983).

12. Allegations of economic discrimination have been scrutinized pursuant to the "rational basis" test since the mid-1930's. At that time, the United States Supreme Court took a decisive step toward establishing the judicial approach to equal protection in the economic realm that has been followed in subsequent years. This modern test evolved as a reaction to the trend of judicial activism that had characterized review of legislation during the 45 preceding years. That approach, which became known as "substantive due process" or "substantive equal protectiou," entailed an exacting scrutiny of the wisdom and substantive validity of statutes of all types. The most widely recognized example of this substantive scrutiny in the economic realm is Lochner $\mathbf{v}$. New York, 198 U.S. 45 (1905), which lends its name to the era. The statute under challeuge in Lochner established maximum hours for bakery employees. Id. at $46 \mathrm{n} .1$. The Court found the state's interference with the right to buy and sell labor to be an unconstitutional exercise of the police power and rejected the state's rationale that it had acted to protect the health of bakers. Id. at 57-58. The Court conducted its own evaluation of the merits of the legislation, exhibiting a lack of deference to the legislative judgment. See id. at 56-58. Utilizing this approach, the Court invalidated many economic regulations during the period, particularly where it suspected the existence of a legislative motive other than protection of the public health and welfare, as in Lochner, id. at 64. See, e.g., Adkins v. Children's Hosp., 261 U.S. 525, 561-62 (1925) (invalidating a minimum wage law for woinen); Coppage v. Kansas, 236 U.S. 1, 26 (1915) (invalidating a statute prohibiting "yellow dog" contracts).

In the mid-1930's, however, the Court reformulated its position on judicial review of economic regulations and began retreating from the activist decisions. Initial retrenchenent from the Lochner approach began in 1934 with Nebbia v. New York, 291 U.S. 502, 539 (1934), in which the Court upheld a state law establishing minimuni retail milk prices. The trend away fron Lochner continued with West Coast Hotel Co. v. Parrish, 300 U.S. 379, 400 (1937), which expressly overruled Adkins. In sharp contrast to the tenor of the Adkins opinion, the Court noted the prerogative of the legislature to consider the situation of women in employment and adopt measures to reduce the evils. Id. at 399. The following year, in United States v. Carolene Prods. Co., 304 U.S. 144 (1938), the Court reiterated its new approach and gave an indication of the proper scope of judicial scrutiny of statutes. Noting its respect for the legislative judgment reached after numerous committee hearings, $i d$. at 148 , the Court stated:

[T]he existence of facts supporting the legislative judgment is to be presumed, for regulatory legislation affecting ordinary commercial transactions is not to be pronounced unconstitutional unless in light of the facts made known or generally assumed it is of such a character as to preclude the assumption that it rests upon some rational basis within the knowledge and experience of the legislators.

Id. at 152. The Court then intimated that certain circumstances nay call for stricter scrutiny: 
local regulations. ${ }^{13}$ The courts look for any rational relation between the purpose for which the statute was enacted and the classification made by the statute. ${ }^{14}$ Operating under a presumption of constitutionahity, ${ }^{15}$ any reasonably related state of facts known or that reasonably could be assumed to have existed at the time of enactment will be deemed to support the legislative judgment. ${ }^{16}$ This standard of mini-

There may be a narrower scope for operation of the presumption of constitutionality when legislation appears on its face to be within a specific prohibition of the Constitution, such as those of the first ten amendments, which are deemed equally specific when held to be embraced within the Fourteenth.

It is unnecessary to consider now whether legislation which restricts those political processes which can ordmarily be expected to bring about repeal of undesirable legislation, is to be subjected to more exacting judicial scrutiny . . . than are most other types of legislation ... [such as that which imposes] restrictions upon the right to vote, ... the dissemmation of imformation, ... political organizations, [or] ... peaceable assembly.

Nor need we inquire whether similar considerations enter into the review of statutes directed at particular religious ... or national . . . or racial minorities, . . . whether prejudice against discrete and insular minorities may be a special condition, which tends seriously to curtail the operation of those political processes ordinarily to be rehed upon to protect mimorities, and which may call for a more searching judicial inquiry.

Id. at 152 n.4.

Since Carolene Products delineated this distimction between infrimgenent of economic rights and fundamental rights, confining the former to a nonrigorous review and reserving stricter scrutiny for the latter, judicial review of economic regulation consistently has been conducted according to the presumption of constitutionality and deference to legislative judgment characteristic of the "rational basis" test. See infra notes 13, 14; see also City of New Orleans v. Dukes, 427 U.S. 297, 303 (1976) ("Unless a classification traminels fundamental personal rights or is drawn upon inherently suspect distinctions such as race, religion, or alienage, our decisions presume the constitutionality of the statutory discriminations and require only that the classification challenged be rationally related to a legitinate state interest.").

13. See City of New Orleans v. Dukes, 427 U.S. 297, 303-04 (1976) ("States are accorded wide latitude in the regulation of their local economies under their police powers. . . [1]n the local economic sphere, it is only the invidious discrimination, the wholly arbitrary act, which cannot stand consistently with the Fourteenth Amendment."); Willianson v. Lee Optical Co., 348 U.S. 483, 488 (1954) ("The day is gone when this Court uses the Due Process Clause of the Fourteenth Amendment to strike down state laws, regulatory of business and industrial conditions, because they may be unwise, improvident, or out of harmony with a particular school of thought.").

14. See Railway Express Ageney v. New York, 336 U.S. 106, 110 (1949) (regulation discriminating between trucks advertising their own business and those carrying advertisements of others rationally related to statutory purpose of traffic safety).

15. See City of New Orleans v. Dukes, 427 U.S. 297, 303 (1976).

16. See United States v. Carolene Prods. Co., 304 U.S. 144, 154 (1930); see also Williamson v. Lee Optical Co., 348 U.S. 483, 487-88 (1954) ("[T] he law need not be in every respect logically consistent with its aims to be constitutional. It is enough that there is an evil at hand for correction, and that it might be thought that the particular legislative measure was a rational way to correct it."). In Lee Optical, the Court upheld a state statute making it unlawful for any person not a licensed optometrist or ophthalınologist to fit, duplicate, or replace lenses into frames without a written prescription, effectively forbidding opticians from fitting or duplicating lenses without a prescription. Id. at 486. While noting that the statute at issue may often exact a "needless, wasteful requirement," id. at 487 , the Court nevertheless rendered a finding of rationality based upon the possibility that the legislature may have concluded that the critical nature of eye examinations and the frequency of occasions when a prescription was necessary justified the regulation. Id. at 
mum rationality is recognized without exception as the appropriate standard for review of legislation in the realms of public welfare and the economy. ${ }^{17}$

\section{Application in Highway Weight Restriction Cases}

Despite agreement as to the appropriate standard of equal protection review in cases challenging highway weight restriction exemptions, the divergence of results demonstrates a lack of consistency in its application. Courts considering very similar statutes under the same "rational basis" test have reached varying results as to their constitutionality. Obviously, different interpretations exist as to the proper scope of scrutiny required under the rational basis test as delimeated by the United States Supreme Court. The cases demonstrate the divergence of results in relatively similar factual situations.

\section{A. Cases Invalidating Exemptions Under the Rational Basis Test.}

State $v^{\text {. Amyot }}{ }^{18}$ involved the prosecution of truckers for violating a highway weight restriction. The New Hampshire Supreme Court considered and struck down a state statute that enabled truckers hauling unprocessed forest products in the northern tier of the state to carry loads that would otherwise violate the weight restriction. ${ }^{19}$ Each of the defendants' vehicles was identical to the exempted vehicles except for the commodity carried and the area of operation. ${ }^{20}$ Noting that truckers carrying unprocessed forest products-as opposed to the processed products carried by the defendants-in the northern portion of the state could carry identical poundage in identical vehicles and avoid prosecution, the court concluded that the statute made an arbitrary distinction

491. See also Kotch v. Board of River Port Comm'rs, 330 U.S. 552, 563-64 (1946) (statute requiring that all vessels sailing through the Mississippi River approaches to the port of New Orleans be navigated by pilots who were state officers upheld, despite nepotism in the appointment process, on basis of presumption that the legislature weighed the evils of a closely knit pilotage system against the objectives of safety and efficiency). Both Lee Optical and Kotch demonstrate the leniency of the "rational basis" test.

17. See supra notes $12-13$ and accompanying text.

18. 119 N.H. 671, 407 A.2d 812 (1979).

19. The court invalidated N.H. Rev. Stat. ANN. § 263:64 VI (Supp. 1977) which provided that a special annual permit allowing excess weight to be carried could be issued to a person transporting unprocessed forest products on designated routes in specified areas of the state. Amyot, 119 N.H. at 672,407 A.2d at 813.

20. The vehicles themselves were identical and thus the defendants met the vehicle and axle requirements for a permit. Id. The defendants were violating the relevant restriction for vehicles without a permit, but were within the limit allowed for vehicles with a permit. Had they been carrying the commodity exempted by the statute in the area specified by the statute, they would not have been subject to prosecution. 
and denied equal protection to the nonexempt truckers. ${ }^{21}$

The court noted that the guarantees of equal protection require a rational relation between the purpose of a statute and the classification that it inakes. Finding no statcd purpose, the court identified the imphicit purposes of the statute as protecting the highways from damage caused by heavy loads, and promoting highway safety. The court held that those aims could be inferred from any overweight truck statute. ${ }^{22}$

The court found the classification made by the statute to be irrational and arbitrary in relation to the purposes of highway mamtenance and public safety. ${ }^{23}$ It rejected the state's argument that because the classification rationally related to the legitimate legislative purpose of promoting the lumber industry in New Hampshire, it was not arbitrary and thus did not violate principles of equal protection. ${ }^{24}$ Relying upon the United States Supreme Court case of Smith v. Cahoon ${ }^{25}$ as well as a recent Idaho case, ${ }^{26}$ the New Hainpshire Supreme Court noted that although furthering the interest of lumbermen may be a proper subject for economic legislation, it bears no relation to public safety or highway maintenance. ${ }^{27}$ The court therefore concluded that favoring lumbermen by creating a classification within a public highway statute violated equal protection guarantees. ${ }^{28}$

The Idaho case of Sterling $H$. Nelson \& Sons $v$. Bender, ${ }^{29}$ on which Amyot relied, ${ }^{30}$ involved a challenge to a state statute that exempted haulers of unprocessed agricultural products fron meeting certain highway weight restrictions. ${ }^{31}$ The defendant being prosecuted for vio-

21. Id. at 674,407 A.2d at 814 .

22. Id. at 673,407 A.2d at 813 (citing Sterling H. Nelson \& Sons v. Bender, 95 Idaho 813, 815,520 P.2d 860, 862 (1974)).

23. The court stated:

We cannot perceive how 90,000 pounds of unprocessed forest products is any less threatening to highway safety or the upkeep of the public ways than 90,000 pounds of any other commodity. Nor do we find any justifiable basis to treat truckers differently in the Id. northern part of the state than they are treated in the southern.

24. Id. at 673,407 A.2d at 813-14.

25. 283 U.S. 553 (1931). The Court in Cahoon invalidated a state statute that exempted carriers of agricultural, horticultural, dairy, and fish products from complance with carrier certification regulations. Id. at 567; see infra notes 54-62 and accompanying text.

26. Sterling H. Nelson \& Sons v. Bender, 95 Idaho 813, 520 P.2d 860 (1974).

27. Amyot, 119 N.H. at 673,407 A.2d at 814 .

28. Id. at $673-74,407 \mathrm{~A} .2 \mathrm{~d}$ at 814 .

29. 95 Idaho 813,520 P.2d 860 (1974).

30. Amyot, 119 N.H. at $673-74,407$ A.2d at 813-14.

31. IDAHO CODE $\S 49-901$ (c) (1967) exempted carriers of logs, pulpwood, poles or pilings, ores, sand and gravel in bulk, and all unprocessed agricultural products, mcluding livestock, from the general weight restrictions, permitting them to carry heavier loads. Sterling $H$. Nelson \& Sons mvolved a challenge to the statutes exemption for carriers of unprocessed agricultural products 
lating the weight restriction was a hauler who would not have been in violation had he been carrying an exempt commodity. As im Amyot, the court looked to the legislative purpose to determine whether the classification was irrational and arbitrarily discriminatory. In so doing it applied a stricter standard than the New Hampshire Supreme Court and more closely scrutinized the relationship between the purposes of the statute and the exemption in order to ascertaim whether all parties similarly situated would be treated alike. ${ }^{32}$

Looking to the nature of the challenged statute, the court found in the weight restrictions a patent purpose of highway protection, supported im this mstance by statutory language. ${ }^{33}$ Like the New Hampshire Supreme Court, the Idaho Supreme Court could not find the requisite relation between the classification made and the purposes sought to be accomplished by the statutory scheme. ${ }^{34}$ Thus, the court

and did not address the other exemptions provided by the statute. See 95 Idaho at 815,520 P.2d at 862.

32. Rather than examining the statute for a "rational relation" between its purpose and the classification that it makes, the court looked to whether the classification rested upon some difference having a "fair and substantial relation" to the object of the statute. Sterling $H$. Nelson \& Sons, 95 Idaho at 815, 520 P.2d at 862 . This rather unusual application of the intermediate tier of equal protection scrutiny between the "rational relation" test generally applied to economic regulations and other exercises of the state police power, see, e.g., Minnesota v. Clover Leaf Creamery Co., 449 U.S. 456, 461 (1981); Williamson v. Lee Optical Co., 348 U.S. 483, 488 (1954), and the "strict scrutiny" test generally applied to statutes involving a suspect class or a fundamental right, see, e.g., Brown v. Board of Educ., 347 U.S. 483, 493-95 (1954) (racial classification presumptively invalid); Roe v. Wade, 410 U.S. 113, 152-53 (1973) (regarding the right to privacy), is most often reserved for cases involving alleged sexual discrimination. See, e.g., Craig v. Boreu, 429 U.S. 190, $197-98$ (1976). The Idaho Supreme Court has simce clarified its approach in Packard v. Joint School Dist., 104 Idaho 604, 661 P.2d 770 (1983). Rather than recognizing the intermediate "substantial relation" test, or "means-focus" test as the court termed it, id. at 607,661 P.2d at 773, as a separate standard of equal protection review, the court incorporated its approach into the rational rclation test, effectively merging the two. Thus, the ratioual relation test as interpreted by the Idaho Supreme Court and applied to cases of economic discrimination, such as Sterling H. Nelson \& Sons, requires not only the existence of a rational relation between a statutory classification and its ascribed purpose, but also that such relationship be fair and substantial. Packard, 104 Idaho at 608,661 P.2d at 774 .

33. The language allowed for excess weight permits as may "be necessary to protect public highways and bridges from injury" and allowed the Board of Highway Directors to make special weight and speed regulations "as may be necessary for the protection of the road or for public safety." Sterling $H$. Nelson \& Sons, 95 Idaho at 815,520 P.2d at 862 .

34. Id. The court was highly critical of the distinction between processed and unprocessed agricultural products, stating that

[t]here is no evidence indicating that 20,000 pounds of processed agricultural commodities are any nore detrimental to the state highway system than 20,000 pounds of unprocessed agricultural commodities, and common sense dictates otherwise. A statute which permits a hauler to transport unprocessed grain to a factory at a weight of 18,900 pounds axle weight, but on the return trip with processed grain only permits a load of 18,000 pounds axle weight, bears no relation to the object of protecting the highways. In the absence of some showing that a safety factor or other exigency requires such a distinction, as in State v. Pyle, 226 Or. 485, 360 P.2d 626 (1961), such a distinction is arbi- 
held that the statute violated the equal protection clause to the extent that it exempted carriers of unprocessed agricultural commodities from meeting the weight limitations. ${ }^{35}$

In holding these statutes unconstitutional, the courts in Amyot and Sterling $H$. Nelson \& Sons deferred in some measure to the legislatures. ${ }^{36}$ Neither court questioned the decision to impose weight restrictions upon vehicles traveling on the highways because a rational basis clearly could be perceived. The courts were not so willing, however, to uphold the classification scheme with an assumption of rationality where none seemed to exist. Rather, they inquired into the relation of the classification to the general statutory purpose. ${ }^{37}$ The courts adhered to the principle that, despite the fact that a legislature is pursuing a presumptively valid state interest in enactimg a regulation, the basis for establishing any exempted class must be rationally related to the object of the regulation in order to ensure equal protection of the laws. Thus, although protection of the highways and promotion of a state industry are both legitimate state interests, their achievement could not properly be pursued within the same regulation, because the relationship between highway regulation and economic development is simply too remote. ${ }^{38}$

trary, unreasonable and without a substantial relation to the purpose of protecting the

highways, and thus violates . . . the Idaho Constitution, and the 14th Amendment of the

U.S. Constitution.

Sterling H. Nelson \& Sons, 95 Idaho at 815-16,661 P.2d at 862. In finding this statute unconstitutional, the Idaho Supreme Court was not unaware of the more deferential approach undertaken in cases such as Pyle that have upheld similar weight restriction statutes. The Idaho court distimguished the Pyle case as involving a classification that was in fact related to the statutory purpose. It therefore did not read the Pyle approach as a blanket prohibition of the review and invalidation of weight restriction statutes. See Sterling $H$. Nelson \& Sons, 95 Idaho at 816, 661 P.2d at 862-63. See also infra notes 39-46 and accompanying text for a discussion of Pyle.

35. Sterling $H$. Nelson \& Sons, 95 Idaho at 816,661 P.2d at 862 . Following the Sterling $H$. Nelson \& Sons decision, the Idaho legislature amended the statute and abandoned the distimction between carriers of processed and unprocessed agricultural products, while retaiming a gcneral exemption for carriers of agricultural products. Act of Mar. 27, 1975, ch. 184, \& 2, 1975 Idaho Sess. Laws 502, 505. At the same time, the legislature reaffirmed the statutory distinctions in favor of certain commercial or farm uses. Id. $\$ 1$, at 502 . The legislature expressly found that the economy of the state depended largely on forest, agricultural, hivestock, mining, and related products and that, because these products are "generally loaded at locations where weighing devices are not available, .... fairness, justice and the pubhic interest dictate that vehicles transporting the[se] products . . . be given a reasonable and adequate weight tolerance." Id. at 502-03.

36. See, e.g., id. at 815,520 P.2d at 862 ("a legislative act is presumed constitutional").

37. See Amyot, 119 N.H. at 673, 407 A.2d at 813 ("The State guarantees of equal protection of the laws mandate "that there be a rational relationship between the purpose of a statute and the classifications which it makes.' ") (quoting State v. Hadley, 115 N.H. 541, 543, 345 A.2d 160, 161 (1975), appeal dismissed, 429 U.S. 802 (1976)); Sterling H. Nelson \& Sons, 95 Idaho at 815, 520 P.2d at 862 (classification must rest "upon some difference having a fair and substantial relation to the object of the legislation").

38. See the approach taken by the Amyot court: 
B. Cases Upholding Exemptions Under the Rational Basis Test.

Other courts have approached and evaluated similar statutes in a less demanding manner than did the New Hampshire and Idaho Supreme Courts, although purportedly applymg the same test. In the case of State v. Pyle, ${ }^{39}$ the Oregon Supreme Court upheld a state statute that exempted vehicles carrying logs, poles, or piling from meetimg the weight restriction imposed on other carriers and granted the favored vehicles a higher weight limitation..$^{40}$ Although the defendant would have been in violation of either limitation, he was subject to a higher fine because he carried a disfavored load. ${ }^{41}$

The court adopted a line of analysis similar to Amyot and Sterling $H$. Nelson \& Sons, addressing the purpose of the statute, the classification, and the relation between the two. The courts differed, however, in applying the rational basis test. The Oregon court was more willing to presume the existence of a rational basis for the classification. ${ }^{42}$ It was not troubled by the fact that the asserted justification of promoting economic development is far removed from the immediate purposes of the

\footnotetext{
The State's argument that the special permit provision rationally relates to the legitimate legislative purpose of promoting the lumber industry in the northern counties, and that the classification it creates is therefore permissible, presumes the wrong analytical approach. Furtherimg the interest of lumbermen, although perhaps a proper subject for economic legislation, has no relation to public safety or highway maintenance. The legislature inay not act to favor lumbermen by creating an arbitrary classification within a pubhic safety chapter.

119 N.H. at 673, 407 A.2d at 813-14. Similarly, the Sterling H. Nelson \& Sons court stated: A statute which [exempts] a hauler [of] . . . unprocessed grain . . . bears no relation to the object of protecting the highways. In the absence of some showing that a safety factor or other exigency requires such a distinction ... such a distinction is arbitrary, unreasonable and without a substantial relation to the purpose of protecting the highways.
}

95 Idaho at $815-16,520$ P.2d at $862-63$.

39. 226 Or. 485,360 P.2d 626 (1961).

40. The Oregon statute established a inaximuin vehicle tandein axle weight of 32,000 pounds for all vehicles except vehicles carrying logs, poles, and piling which were allowed a maximum vehicle tandem axle weight of 34,000 pounds. See id. at 487,360 P.2d at 627 .

41. The defendant's vehicle weighed 34,100 pounds. Had he been carrying logs, poles, or piling the vehicle would have been 100 pounds overweight and he would have incurred a fine of $\$ 25$. Because he was not carrying an exempted commodity, the vehicle was 2,100 pounds overweight and he incurred a fine of $\$ 63$. Id.

42. Extremely deferential to the legislature, the court readily assumed that a rational reason for establishing the classification existed:

Legislation usually is the product of the adjustment of various interests. The factors considered by the legislature in inaking these adjustments do not ordinarily appear in the statute which is the end product of the legislative process. It is patent that the principal concern of the legislation. . . was the preservation of the highways. It seems equally obvious that the legislature found that the enactment of such legislation required an adjustment of the interests of the haulers of logs, poles and piling. The reasons for selecting this one class of commodities for special treatment are not exphcitly stated in the statutes. But that is no obstacle in sustaining the legislation if there is any rational basis for such treatment.

Pyle, 226 Or. at 489-90, 360 P.2d at 628-29 (citations omitted). 
regulation-highway protection and public safety. ${ }^{43}$ Rather, it expressly recognized the right of the legislature to pursue two separate but legitimate goals under the guise of one. ${ }^{44}$ Thus, a highway weight regulation may serve both to protect the highways and to promote a favored state industry. ${ }^{45}$ Despite these assertions, however, the court also set forth in great detail the manner in which the classification was related to the general statutory purpose of highway safety. 46

A federal district court upheld a similar state statute in Gutridge v. Virginia. ${ }^{47}$ The statute at issue exempted four distinct classes from meeting general weight restrictions, allowing the exempted classes to operate within higher limits. ${ }^{48}$ The carriers challenging the statute were not eligible for the exemption under the language of the statute. They were, however, capable of hauling the same bulk commodities specified-concrete, coal and farm produce. 49

The court applied the rational basis test $m$ a fashion that seems to

43. "The special treatment afforded to haulers of logs, poles or piling could be justified here if only on the ground that the legislature desired to foster the logging industry through the special benefits afforded to those hauling the raw products of the forests." Id. at 490, 360 P.2d at 629 (citing Anderson v. Thomas, 144 Or. 572, 615, 26 P.2d 60, 75 (1933) (Anderson upheld a transportation tax favoring carriers of logs, pilings, poles, and rough timber and recognized the importance of the lumbering business to the state and the state interest in encouraging its development)).

44. [T] he assunption that the only possible purpose which the legislature could have had in mind in enacting the overload statutes was the preservation of the highways is a purely gratuitous assumption. The inere fact that the principal purpose of the legislation was to preserve the highway does not inean that the legislature may not also have had other considerations in mind.

Pyle, 226 Or. at 489,360 P.2d at 628.

45. Id.

46. The court apparently was not coinpletely at ease with its previous assertion that exemptions from weight restrictions inay be based upon grounds totally unrelated to the object of the highway regulation itself. It proceeded to establish how the basis for the exemption could in fact be rationally related to the object of the statute. The court referred to the state's arguments and the legislative history of the weight restriction statute that set forth reasons for the special treatment of haulers of forest products. Id at $491-92,360$ P.2d at 629 . These included the facts that the logs usually are loaded in the woods where it is impractical to provide scales and that it is difficult to estimate accurately the weight and distribution of a load given the variations among logs, and, most directly related to the statutory purpose, the possibility that hauling these cominodities presents less of a menace to the highways because they are liauled over unimproved roads for a substantial part of their journey and are transported over the highways for a rclatively short time compared to most other goods. Id. Thus, the Oregon Supreme Court actually seemed to conclude that the 2,000 pound "leeway" was indeed rationally related to the highway safcty and maintenance goals and was therefore not "unreasonable or arbitrary." Id. at 492, 360 P.2d at 629-30.

47. 532 F. Supp. 533 (E.D. Va. 1982).

48. The exempted classes include vehicles carrying containerized cargo in sealed, seagoing containers, bound to or fron a Virginia seaport, three-axle vehicles used exclusively for transporting necessary components to produce concrete immediately upon arrival at a project site, special vehicles used in hauling coal to a preparation plant, loading dock, or railroad, and trucks hauling farm produce on the Eastern Shore. See VA. CODE \$\$ 46.1-343(a)(2),(b)(1),(c), 343.1 (Supp. 1984).

49. Gutridge, $532 \mathrm{~F}$. Supp. at 536. 
place Gutridge on a scale of scrutiny between Amyot and Pyle.50 The court did not go as far as Pyle in asserting that there need be no relation between the exeinption and the purpose of the regulation, but was willing to presume a legitimate state interest and rational basis for each classification. The court strained to relate the "rational basis" for each exeinption to the general area of transportation..$^{51}$ The effective standard of review apphed by the court appears to have been largely perfunctory. It is unlikely that a statute would be invahdated pursuant to such an undemanding standard. ${ }^{52}$

50. Id. at 537. According to the court, the rational basis test "requires only that the State's systein be shown to bear some rational relationship to legitimate state purposes." Id. at 536 . The court did not specifically address whether a regulation and its exemptions could "rationally" pursue two distinct legitimate state purposes, as did the court in Pyle, see supra notes $43-46$ and accompanying text, or, conversely, whether a regulation and its exemptions must be based upon the same legitimate state purpose to be rational, as in Amyot, see supra notes 23-28 and accompanying text, and Sterling $H$. Nelson \& Sons, see supra notes 34-35 and accompanying text.

51. The court's treatinent of the first exemption, involving containerized cargo, is perplexing. The court identified several possible legitimate state objectives and then summarily presumed the existence of a rational basis as follows:

Encouraging the growth of a particular form of transportation is a legitinate legislative purpose. . . . Containerized cargo is an integral part of international trade. Facihtating its transportation to and from Virginia's ports aids in the development of such ports. Thus, the containerized cargo exception stands up under a rational-basis exainination.

Gutridge, 532 F. Supp. at 537. As to the concrete-mixer exemption, the court noted that these speciahzed vehicles weigh more than others. Id. The exemption limited the distance and speed of their travel to low levels, so the court found that a rational basis existed for relaxing the weight restrictions. Id. As to the coal hauling exemption, the court identified two legitinate state objectives that rendered it rational: promoting the efficient transportation of coal and aiding the enforcenent of weight limits, presumably because the exemption required that any qualifying vehicle must be designed to permit a visual determination of whether it was carrying inore than the permitted anount of coal. VA. CoDE \$ 46.1-343(c) (Supp. 1984); see Gutridge, 532 F. Supp. at 535-36. The fourth exemption, for farm products hauled on the Eastern Shore, was handled much like the first one. The court identified several possible state objectives, including the promotion of a state industry. That objective was somehow integrated among other transportation-oriented objectives, resulting in a determination of rationality:

The seasonal nature of farming limits the use of this exception to the warmer months of the year when the potential for road dainage is least. In addition, the pecuhar geography of the Eastern Shore creates transportation impediments that place farmers in that area at a disadvantage in inarketing their produce. A shortage of vehicles in the region compounds the problem. The relaxation of weight limits reduces the number of trucks needed to haul the produce. [The exeinption], therefore, furthers the legitinate legislative goal of remedying the Eastern Shore's transportation difficulties.

Id. at 537.

52. The court evidenced a concern that requiring a strong correlation between the exemption and the purpose of the regulatory scheme would revive the notion of economic due process. "If the court had overturned one of the exceptions in the absence of a suspect classification or a fundamental right, it, in effect, would have revived the notion of economic due process. The Supreme Court discarded that form of due process long ago." Gutridge, 532 F. Supp. at 537 (citmg Williamson v. Lee Optical Co., 348 U.S. 483, 488-89 (1954); see also Day-Brite Lighting, Inc. v. Missouri, 342 U.S. 421, 423-25 (1952)); supra notes 12-13 and accompanying text. 


\section{Evaluation of the Highway Weight Restriction Cases}

As demonstrated by the preceding cases, courts have varied as to the appropriate scope of judicial review pursuant to the rational basis test and, correspondingly, the proper measure of deference owed to a legislature in the areas of police power and economic regulation. The inquiry here is whether one approach is clearly superior. Ostensibly involved in state regulation of highways is the state's police power to legislate for public health and safety and protection of roads, and its power to regulate economic activity. The legislature is given wide discretion in each of these areas. ${ }^{53}$ Whetler an exeinption can be successfully challenged depends upon the extent to which the court will search for a legitimate legislative purpose rationally related to the statute, and whether the court will require that an exemption correspond to the overall purpose of the statutory scheme.

Central to the validity of both Amyot and Sterling H. Nelson \& Sons is the United States Supreme Court case of Smith v. Cahoon. ${ }^{54}$ At issue in Cahoon was an exemption from a state statute that required carriers to obtain certificates of public convemence and necessity. To obtain such a certificate, those not exempt were required to post bond or to obtain insurance for the protection of passengers, other members of the public, and freight. ${ }^{55}$ In apparent disregard of this stated purpose, the legislature based availability of an exeinption upon the type of commodity carried. Vehicles exclusively engaged im transporting agricultural products, dairy products, and seafood were relieved from the obligation of providing imdemnification to the public. ${ }^{56}$

The Court acknowledged the right of a state to issue such a regulation and noted that the exemptions alone did not render it repugnant to the equal protection clause. ${ }^{57}$ The Court stressed, however, that despite the broad discretion permitted a state in the formulation of classifications for the purpose of regulation, the power was not without limitation. The equal protection clause provides a constraimt against entirely arbitrary distinctions. ${ }^{58}$

53. See, e.g., Bibb v. Navajo Freight Lines, 359 U.S. 520, 523 (1959); United States v. Carolene Prods. Co., 304 U.S. 144, 152 (1938).

54. 283 U.S. 553 (1931).

55. Id. at $558-59$.

56. The relevant portion of the Florida statute exempted those "engaged exclusively in the transporting [of] agricultural, horticultural, dairy or other farm products and fresh and Salt Fish and Oysters and Shrimp from the poimt of production to the assembling or shipping point enroute to primary market or to motor vehicles used exclusively in transporting or deliverimg dairy products." Id. at 557.

57. Id. at 556.

58. Id. at 566-67. 
In order to determine whether the classifications were in fact arbitrary as alleged, the Court looked to the general purpose of the regulation and identified it as one of promoting public safety and welfare. ${ }^{59}$ The indemnification regulation was rationally related to this legitimate legislative objective. ${ }^{60}$ The Court, however, could find no rational relation between the legitimate legislative objective and the exemptions created by the statute. ${ }^{61}$ The Court determined that distimctions based upon the type of commodity carried were totally unrelated to the purpose of public safety and welfare, and invalidated the exemption as denying equal protection to those not exempt. ${ }^{62}$ Clearly, under $\mathrm{Ca}$ hoon, the fact that a classification rationally relates to any legitimate state objective is imsufficient for equal protection purposes. The classification must be rationally related to the objective pursued by the legislative enactment.

Cahoon would provide unassailable support for the approach taken in Amyot and Sterling H. Nelson \& Sons were it not for the fact that it was decided in 1931, when the Supreme Court was reaching the end of the Lochner era. ${ }^{63}$ It may thus be argued that Cahoon should be disregarded as the product of an illegitimate era. There is also support, however, for the contrary proposition that judicial review of the relationship of a classification to the alleged purpose of a statutory scheme does not necessarily involve an inquiry into the substantive wisdom of a legislative decision and is not prohibited by post-Lochner era cases.

59. The purpose of the bond was to afford security for the public against injuries and to protect the persons and property transported. Id. at 565 .

60. Id.

61. The analogy between the statutory classifications in Cahoon and the highway weight restriction exemptions is obvious. Just as there is no rational basis, grounded in a concern for public safety, for exempting carriers of shrimp, milk, or corn from furnishing the insurance that all other carriers are required to furnish, there is also no rational basis, grounded in a concern for public safety or highway maintenance, for exempting carriers of poultry, milk, or corn from ineeting the highway weight restrictions that all other carriers must ineet.

62. The Court stated:

In determining what is within the range of discretion and what is arbitrary, regard inust be had to the particular subject of the State's action. In the present instance, the regulation as to the giving of a bond or insurance pohicy to protect the public generally, in order to be sustained, must be deemed to relate to the public safety. [There is] no doubt of the power of the State to insist upon suitable protection for the public against injuries through the operations on its highways of carriers for hire. . . . But, in estabhishing such a regulation, there does not appear to be the slightest justification for making a distimction between those who carry for hire farm products, or milk or butter, or fish or oysters, and those who carry for hire bread or sugar, or tea or coffee, or groceries in general, or other useful cominodities. So far as the statute was designed to safeguard the public with respect to the use of the highways, ... the discrimination it makes . . was wholly arbitrary and constituted a violation of the appellant's constitutional right. "Such a classification is not based on anything having relation to the purpose for which it is made."

Cahoon, 283 U.S. at 567 (quoting Air-Way Elec. Apphance Corp. v. Day, 266 U.S. 71, 85 (1924)).

63. See supra notes $12-13$ and accompanying text. 
The deference that modern courts afford legislatures when they exercise tlie police power to protect the public welfare or enact an economic regulation reflects an unwillingness to return to the highly imterventionist Lochner era of substantive equal protection-a period during which courts employed the fourteentli amendment to strike down laws perceived to be based upon imprudent legislative judgment. ${ }^{64}$ Under the rational basis standard of review developed in reaction to the Lochner era, courts are im effect prohibited from intruding upon legislative value judgments and substituting their own social and economic beliefs for the discretion of those elected to legislate. ${ }^{65} \mathrm{Dis}-$ timctions and discriminations imposed by state laws do not violate the equal protection clause so long as they are not irrational, arbitrary, or invidious. ${ }^{66}$

Some courts have taken this to mean that judicial inquiry into any aspect of a police power or economic regulation necessarily entails a return to the forbidden Lochner era. ${ }^{67} \mathrm{~A}$ fear of violating this understanding of the post-Lochner era was apparent in the manner in which the Pyle and Gutridge courts summarily conceded the existence of a rational basis for the exemptions being challenged. ${ }^{68}$ Despite this suinmary conclusion, both courts addressed the relationship between the purpose of tlie statute and the classifications that it made and inquired whether it was rational. The Gutridge court attempted to tie each statutory exemption to a transportation theme, ${ }^{69}$ and the Pyle court discovered possible higliway maintenance rationales that could support the statute. ${ }^{70}$ Even those courts most reluctant to engage in a Lochner-type review implicitly acknowledge the significance to tlie doctrine of equal protection of tlie relationship between the purpose of a statute and the classifications that it makes.

Significantly, Cahoon, unlike other products of the Lochner era,

64. See supra note 12.

65. See, e.g., Olsen v. Nebraska ex rel. Western Reference \& Bond Ass'n, 313 U.S. 236, 246 (1941) ("We are not concerned ... with the wisdom, need, or appropriateness of the legislation.").

66. Harper v. Virginia Bd. of Elections, 383 U.S. 663, 673-74 (1966) (Black, J., dissenting) ("The equal protection cases carefully analyzed boil down to the principle that distinctions drawn and even discriminations imposed by state laws do not violate the Equal Protection Clause so long as these distinctions and discriminations are not irrational, irrelevant, unrcasonable, arbitrary, or invidious.").

67. See, e.g., Gutridge, 532 F. Supp. at 537.

68. See supra notes 42,51 and accompanying text.

69. See supra note 51 and accompanying text.

70. See supra note 46 and accompanying text. 
has never been expressly overruled. ${ }^{71}$ Indeed, it has been cited by the Supreme Court in subsequent decisions without any suggestion of its invalidity.72 For example, Cahoon was distinguished and endorsed by the Court in Sproles v. Binford, ${ }^{73}$ which the Court repeatedly has up-

71. Adkins v. Children's Hospital, 261 U.S. 525 (1923) was expressly overruled in West Coast Hotel Co. v. Parrish, 300 U.S. 379, 400 (1937). Lochner v. New York, 198 U.S. 45 (1905), and Coppage v. Kansas, 236 U.S. 1 (1915), were rejected in Lincoln Fed. Labor Union v. Northwestern Iron \& Metal Co., 335 U.S. 525, 535-36 (1949). Adains v. Tanner, 244 U.S. 590 (1917) was also recognized as undermined in Lincoln Federal Labor Union, 335 U.S. at 535. Adams had held a state statute prohibiting a "useful" business to be in violation of the fourteeuth amendment. 244 U.S. at 596-97.

72. See, e.g., Moore v. City of E. Cleveland, 431 U.S. 494, 513 (1977) (Brennan, J., concurring); Bullock v. Carter, 405 U.S. 134, 145 (1972); Labine v. Vincent, 401 U.S. 532, 551 (1971) (Brennan, J., dissenting); Harper v. Virginia Bd. of Elections, 383 U.S. 663, 674 n.2 (1966) (Black, J., dissenting); Sproles v. Binford, 286 U.S. 374, 394 (1932).

Interestingly, of the post-Lochner era cases in which the Court has cited Cahoon, only one has entailed the invalidation of a state econonic regulation on equal protection grounds. See Morey v. Doud, 354 U.S. 457, 458 (1957) (striking down a provision of the Illinois Commuuity Currency Exchauges Act that exempted money orders of the American Express Company from the statute's requirement that firms selling or issuing money orders in that state must secure a license and submit to state regulation). The Court rehed on both Williamson v. Lee Optical Co., 348 U.S. 483 (1954) and Cahoon without noting any apparent imconsistency in their approaches. 354 U.S. at 465. The Court noted the wide scope of discretion granted the state in the enactment of and classifications within police laws, the propriety of judicial invalidation only where a statute "is without any reasonable basis and therefore is purely arbitrary," and the principle that any state of facts unust be assumed that reasonably can be conceived to sustain a classification. Doud, 354 U.S. at 463-64. It was further noted that the " "prolribition of the Equal Protection Clause goes no further than the invidious diserimination." "Id. at 463 (quoting Lee Optical Co., 348 U.S. at 489). Subsequently, the Court cited Cahoon for its assertion that "a statutory discrimination must be reasouably related to the purposes of the Act in which it is fonnd." Id. at 465.

Doud has since been overruled in City of New Orleans v. Dukes, 427 U.S. 297, 306 (1976). The Court failed, however, to suggest the invalidity of Cahoon or to disniss exphicitly the need for some rational relation between a statutory classification and the object of that statute. The Court reiterated the principle that "in the local economic sphere, it is only the invidious discrimination, the wholly arbitrary act, which cannot stand consistently with the Fourteenth Amendment." Id. at 303-04. The Court failed to state whether a classification must be ratioually related to the same legitimate state interest with which the statute deals. See id. at 303 . The holding of the case, however, may provide some guidance. New Orleans had enacted a prohibition against selling foodstufis froni pushcarts in the Freuch Quarter, but had exempted vendors with eight years or more seniority. The Court sought to demonstrate that the exemption was rationally related to the statutory objective of "preserv[ing] the appearance and custoin valued by the Quarter's residents and attractive to tourists." Id. at 304. The exempted vendors "had themselves become part of the distinctive character and charm that distimguishes the [French Quarter]." Id. The Court found additional support for the exemption in the possibility that the legislature had decided to proceed on a gradual basis, ratioually eliminating the more recent vendors initially. Id. This principle of gradual implementation was first enunciated in Lee Optical Co., 348 U.S. at 489 ("[R]eform may take one step at a time, addressing itself to the phase of the problem which seems inost acute to the legislative mind.").

73. 286 U.S. 374, 394 (1932). At issue in Sproles was a state statute exempting farm vehicles and vehicles making hauls of less than eight miles from ineeting highway weight restrictions. $I d$. at 391-92. The Court upheld the statute on the ground that the use of the highways by such vehicles was relatively brief and confined to sinall areas. Id. at 392 . Even if the classification was 
held and cited in support of anti-Lochner positions. ${ }^{74}$ Additionally, Professor John Hart Ely, a leading commentator in the field, has argued that Cahoon "is not simply a derelict surviving from the 'overactive' early 1930's."75 Rather, it is a legitimate equal protection case in which the Court has applied a "sort of 'consensus' theory, asking not what motivation underlay the specific distinction in question, but rather what such laws are generally concerned with, what most legislators intend to accomplish by most such laws considered in their entirety."76 Thus a court may follow the approach of Cahoon, as im Amyot and Sterling H. Nelson \& Sons, without risking a retreat to Lochner.

In his exammation of judicial equal protection analysis, Ely poimted to the process of goal definition ${ }^{77}$ by which permissible and impermissible goals are distimguished, and rejected the notion that once a goal is deemed permissible in one context, its pursuit is per se permissible in all contexts. ${ }^{78}$ Accordingly, under Ely's theory, a classification

also intended to encourage transportation by railroad instead of by truck, the Court added, its constitutionality was still ensured given the rational relation between reducing the flow of traffic and inaintaining the condition of the roads. Id. at 394. Thus, the Court noted:

This is not a case of a denial of the use of the highways to one class of citizens as opposed

to another, or of limitations having no appropriate relation to highway protection. It is

not a case of an arbitrary discrimination between the products carried, as in the case of

Smith v. Cahoon, 283 U.S. 553, 567.

Sproles, 286 U.S. at 394.

74. See Ferguson v. Skrupa, 372 U.S. 726 (1963), a case very critical of the Loc/iner era. Ferguson quoted Sproles, 286 U.S. at 388, for the proposition that the Court does not sit to "subject the State to an intolerable supervision lostile to the basic principles of our Government and wholly beyond the protection which the general clause of the Fourteenth Amendinent was intended to secure." Ferguson, 372 U.S. at 730.

75. Ely, Legislative and Administrative Motivation in Constitutional Law, 79 YALE L.J. 1205, 1225-26 (1970). Ely attempts to reconcile the various approaches that the Supreme Court has undertaken in equal protection analysis. He is critical of the Court's inconsistency regarding the relevance of legislative "motive" or "purpose" to the constitutionality of a statute, id. at 1207-12, and attempted to formulate a useful inodel for guidance as to the circumstances under which inotivation is relevant. Id. at 1281-84.

76. Id. at 1226.

77. Id. at 1224-25. As presented by Ely, a basic issue addressed by equal protection analysis is the burden that the government owes with respect to distinctions that invariably treat some persons better than others. Meeting this burden initially requires the government to "poimt to some difference which distinguishes the persons or items on one side of the line its action has drawn [from] those on the other." Id. at 1223. Recognized in the process of determining whether this distimction constitutes a "legitimately defensible difference" is the fact that the government will have a different type of burden to bear depending upon the nature of the classification or the substantiality of the benefit or deprivation at stake. Id. at 1223-24. Where a choice is properly related to a legitmiate goal, it will constitute a "legitimate defense" in an equal protection evaluation. Id. at 1224 .

78. Id. at 1224-25. Ely asserts that government officials should not be privileged to pursue a goal in any context nerely because that goal may legitinuately be pursued in another context. He demonstrates this by suggesting a clearly unacceptable scenario which could otherwise arise: Be- 
may be examined to determine whether it rationally relates to the purpose of the statute, without challenging the wisdom of the legislature's action or necessarily engaging in the type of inquiry into legislative motivation and judgment reminiscent of the Lochner era. ${ }^{79}$

Ely's position as to the validity of Cahoon and his theory regarding the permissible scope of judicial review under the nodern rational basis test go far toward endorsmg the approach taken in Amyot and Sterling H. Nelson \& Sons. This approach has not been confined to the area of highway weight regulation, but has extended to other exercises of the police power resulting in economic discrimination. In Goodman v. Kennedy, ${ }^{80}$ for example, the Pennsylvamia Supreme Court considered the constitutionality of two statutory provisions that exenpted certain types of stores from a criminal provision forbidding the sale of fresh meats, produce, and groceries on Sunday. ${ }^{81}$ Although referring to the wide degree of latitude accorded the legislature in inaking such classifications, ${ }^{82}$ the court noted the requirenent that legislative classifications be reasonably related to legitimate statutory objectives. ${ }^{83}$ After identifying the valid statutory purpose of providing a day of rest and recreation for nembers of the public, the court sustained an exemption for businesses employing less than ten persons as rationally related to that goal. ${ }^{84}$ The court refused, however, to uphold a provision that ex-

cause farming can constitutionally be encouraged with subsidies, a statute could be enacted that would attempt to encourage farming by limiting driver's licenses to farmers or free public education to their children. Id. at 1224. Ely also argues that "numerous decisions of the Court make clear that it is not prepared to recognize as acceptable in all contexts all goals it is prepared to recognize as acceptable in some." Id. at 1224-25. See, e.g., Reynolds v. Sims, 377 U.S. 533 (1964) (holding that farming can be made more attractive by subsidies and tax breaks, but not by weighing farmers' votes more heavily), cited in, Ely, supra note 75, at 1227.

79. Thus, where a law obviously lias to do with traffic safety, a court may loold, regardless of the underlying motive, that the specific classification at issue must be justifiable in terms of safety. Likewise, a subsidy program or a tax program may be an appropriate vehicle for legislative promotion of an activity which advances the general welfare or safety, but a motor vehicle code is not. Ely, supra note 75 , at 1226 .

80. $459 \mathrm{~Pa} .313,329$ A.2d 224 (1974).

81. Id. at $318-19,329$ A.2d at 227.

82. The legislature has the constitutional authority to establish different classifications of persons and to provide for different treatment of the classifications under the law so long as the basis for each is reasonably related to the evils sought to be prevented. . . "The constitutional safeguard is offended only if the classification rests on grounds wholly irrelevant to the achievement of the State's objective. State legislatures are presumed to have acted within their constitutional power despite the fact that, in practice, their laws result im some imequality. A statutory discrimination will not be set aside if any state of facts reasonably may be conceived to justify it."

Id. at 321, 329 A.2d at 228 (quoting McGowan v. Maryland, 366 U.S. 420, 425-26 (1961)).

83. Id. at 325,329 A. $2 \mathrm{~d}$ at 230 .

84. Id. The court concluded that public enjoyment of a day of rest and recreation could be enhanced by the einployment of some and the recreation of others and that the number selected was a reasonable distinction. By stating that a mathenatical limit as a basis for classification is 
empted businesses operated by the proprietor or members of his family on the ground that a distmction based solely upon fanily status is not rationally related to the primary statutory objective and is therefore unconstitutionally discriminatory. ${ }^{85}$

The inost obvious conclusion to be drawn from the divergent cases is that there exist viable arguments in support of both approaches to the constitutionality of highway weight restrictions. These approaches reflect the differing views of the courts as to the proper degree of deference to be accorded highway weight restrictions. Pyle and Gutridge regard the modern rational basis test as endorsing legislative pursuit of any legitimate goal in any realm, ${ }^{86}$ while Amyot and Sterling H. Nelson \& Sons interpret the test to be inore confining, prohibiting the pursuit of a goal in one regulatory context although permitting it in another. ${ }^{87}$

The resolve of the Pyle and Gutridge courts to avoid judicial review reminiscent of the Lochner era is understandable given the modern Court's complete disavowal of that period. ${ }^{88}$ The fact that the statutes at issue were enacted pursuant to tlie police power and resulted in discrimination of an economic nature reinforces this approach. As noted previously, courts exhibit a great amount of deference when statutes are enacted pursuant to the police power ${ }^{89}$ and employ the least rigorous standard of review when the alleged discrimination is economic in nature. ${ }^{90}$

It may be, however, that the courts in Pyle and Gutridge were extreine in their efforts to avoid "Loclmerizing." An examination of the relationship between the object of a highway weight restriction statute

constitutional if the number bears a rational relation to a legitimate legislative objective, the court implied that a distinction drawn at 10,000 would have been deemed irrational and unconstitutional. Id. at 322,329 A.2d at 229.

85. Id. at 326-27, 329 A.2d at 231. Because the exemption gave an economic advantage to certain groups solely because of the degree of consangumity, other groups similarly situated except for this factor were placed at an economic disadvantage. The factor at issue was unrelated to the overall statutory purpose. The court cited Cahoon, 283 U.S. at 566-67, to conclude:

Econornic discrimination, in and of itself, is not a legitimate legislative objective which justifies the closing of some stores on Sunday and not others. Economic discrimination can be tolerated coustitutionally only when it is incidental to some other legitimate legislative objective. A classification based on family status might be reasonably related to a legitimate legislative objective in other contexts, even though economic discrimination incidentally results, but we are unable to perceive any reasonable relationship in the present context. Without such relationship, the family status classification violates the equal protection clause of the fourteenth amendment.

Goodman, $459 \mathrm{~Pa}$. at 326-27, 329 A.2d at 231.

86. See supra notes $42-45 \& 50-52$ and accompanying text.

87. See supra notes $23-28 \& 32-38$ and accompanymg text.

88. See supra notes $12-13$ \& 16 .

89. See supra notes 4,13 and accompanying text.

90. See supra notes $12-13$ and accompanying text. 
and the classifications that it inakes does not necessarily entail an inquiry into the substantive wisdom of a legislative decision. Indeed, the courts in Amyot and Sterling H. Nelson \& Sons, in contrast to the Lochner Court, did not debate whether the legislatures had made reasoned decisions based upon accurate facts. ${ }^{91}$ The courts identified two legislative objectives at work, both legitimate, and rehed upon the Cahoon precedent to determine that the pursuit of one objective under the guise of the other is impermissible inasmuch as it entailed a wholly arbitrary classification. ${ }^{92}$

Basic notions of fairness upon which the equal protection clause rests justify the approach of the Amyot and Sterling $H$. Nelson \& Sons courts. Many of the weight restriction exeinptions exist for the purpose of favoring a particular industry. ${ }^{93}$ Although such special treatment is ostensibly a function of concern for the state economy, often it is instead a function of persuasive campaign contributions and the disproportionate influence of lobbying interests. Although such pressures and incentives are inherent in the pohitical systein, fairness and equal protection are best served when a lawmaker cannot conceal a special favor under the guise of a nore readily acceptable legislative objective. If the legislature chooses to treat a certain industry with favor, Amyot and Sterling $H$. Nelson \& Sons force it to do so in a straightforward maimer-by granting favorable tax treatment or instituting a subsidy program. ${ }^{94}$ Because the discriminatory classifications inade by highway weight restriction statutes are wholly unrelated to the evils such statutes generally seek to prevent, the classifications appear susceptible to challenge on equal protection grounds.

\section{Conclusion}

Froin the standpoint of basic fairness, decisions invahdating discriminatory highway weight restriction exemptions on equal protection grounds seem correct. Whether their interpretation and application of the modern rational basis test is in accord with the present intent of the United States Supreme Court is less clear. The Court certainly has restricted the extent of judicial scrutimy permitted in this area. The level of scrutiny once undertaken in economic classifications is now reserved for situations in which a fundamental right or suspect class is affected. Nevertheless, the Court has not expressly overruled Cahoon or its

91. Lochner v. New York, 198 U.S. 45, 61 (1905) ("We do not believe in the soundness of the views whiclt uphold this law.").

92. See supra notes $23-28,34$ \& $37-38$ and accompanying text.

93. See supra notes $38,42,51 \& 62$ and accompanying text.

94. See supra uotes 78-79. 
premise that a classification must bear a rational relation to the purpose of the statute. The Court's continued prohibition of irrational, irrelevant, or unreasonable classifications imposed by state law would seem to permit the Amyot and Sterling H. Nelson \& Sons approach. This approach allows for the imvalidation of those weight restriction exemptions that are in no way related to public safety and highway maintenance.

Lorrie M. Marcil 